\title{
Analisa Pengaruh Customer Experience Terhadap Customer Satisfaction Wisatawan Pada Destinasi Wisata Kabupaten Bintan Kepulauan Riau
}

\author{
Iranita \\ Fakultas Ekonomi Universitas Maritim Raja Ali Haji, Tanjungpinang, Kepulauan Riau, Indonesia
}

\begin{abstract}
ABSTRAK : Penelitian ini membahas tentang customer experience yang diduga mempengaruhi customer satisfaction wisatawan di Kabupaten Bintan Provinsi Kepulauan Riau. Dalam penelitian ini variabel experinece diukur melalui dimensi sense, feel, think, act dan relate. Data penelitian diolah dengan menggunakaan analisa faktor dan regresi linier berganda. Hasil dari penelitian ini menunjukkan bahwa variabel customer experience berpengaruh signifikan dan positif terhadap kepuasan konsumen (customer satisfaction). Hasil dari penelitian menunjukkan bahwa variabel experience dengan dimensi sense, feel, think, act dan relate berpengaruh secara simultan terhadap satisfaction customer. Secara parsial dimensi faktor sense, feel, think dan relate yang memberikan pengaruh yang siginifikan terhadap satisfaction customer dan dimensi sense pengaruhnya dominan terhadap satisfaction customer.
\end{abstract}

Kata kunci: Customer Experience, Customer Satisfaction

\begin{abstract}
This study discusses the customer experience that supposedly affects customer satisfaction of tourists in the province of Riau Islands of Bintan Regency. In this study the variable dimension measured through experinece sense, feel, think, act and relate. Research data processed with using their analysis of multiple linear regression and factor. The results of this research show that customer experience significant influential variable and positive towards consumer satisfaction (customer satisfaction). The result of the research shows that experience variable with dimensions of sense, feel, think, act and relate simultaneously against influential customer satisfaction. In partial dimensions factor sense, feel, think and relate that give may influence against the satisfaction and sense of dominant influence dimensions against customer satisfaction.
\end{abstract}

Keyword: Customer Experience, Customer Satisfaction

Email Address : iranita27@gmail.com / iranita@umrah.ac.id 


\section{Pendahuluan}

Provinsi Kepulauan Riau merupakan provinsi yang penuh dengan limpahan rahmat dari Tuhan Yang Maha Kuasa. Selain letak geografisnya yang sangat strategis karena berada pada pintu masuk Selat Malaka, Brunei dan Provinsi Kalimantan Barat dari sebelah Timur, juga berbatasan dengan pusat bisnis dan keuangan di Asia Pasifik yaitu Singapura. Di samping itu Provinsi Kepulauan Riau juga berbatasan langsung dengan Negara-negara ASEAN selain Singapura juga Negara Malaysia dan Vietnam.

Dari data Statistik (BPS Kepulauan Riau, 2016) Jumlah wisatawan mancanegara (wisman) yang berkunjung ke Provinsi Kepulauan Riau pada bulan Juli 2016 mencapai 151.972 orang, mengalami penurunan sebesar 13,33 persen dibanding jumlah wisman pada bulan sebelumnya yang mencapai sebanyak 175.348 orang. Dibandingkan dengan Juli 2015 kunjungan wisman Juli 2016 mengalami kenaikan, yaitu sebesar 3,67 persen.Wisman yang berkunjung ke Provinsi Kepulauan Riau pada bulan Juli 2016, sebesar 72,34 persen masuk melalui pintu masuk yang ada di Kota Batam dengan jumlah wisatawan 109.931 orang. Wisman yang berkunjung ke Provinsi Kepulauan Riau pada bulan Juli 2015 didominasi oleh wisman berkebangsaan Singapura dengan persentase sebesar 46,54 persen dari jumlah wisman pada Juli 2015.

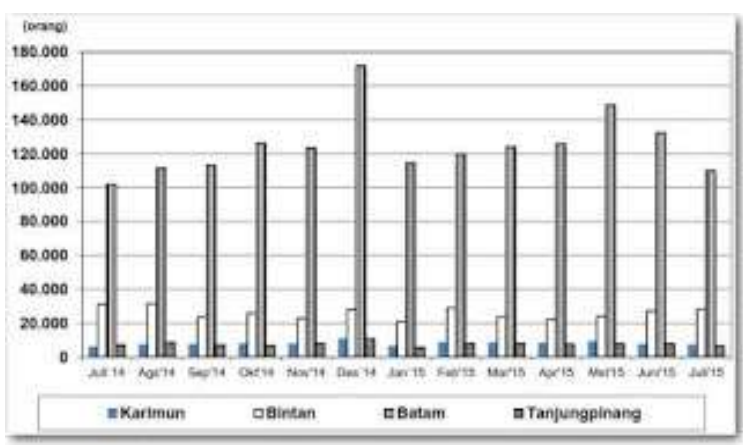

Grafik 1.1

Perkembangan Kunjungan Wisatawan
Mancanegara ke Provinsi Kepri menurut

Kabupaten/Kota Juli 2015 s.d. Juli 2016

Dari gambar di 1.1 dapat dijelaskan bahwa dari 7 (tujuh) Kabupaten Kota yang ada di Provinsi Kepulauan Riau yang paling mencolok adalah Batam dan Kabupaten Bintan. Pada kenyataannya nama Batam tidak asing lagi bagi turis, tapi masih ada "surge tersembunyi" di Kepulauan Riau yang memiliki banyak pantai perawan, namanya pulau Bintan. Khususnya Kabupaten Bintan memiliki banyak objek wisata alam yang dikembangkan dan sudah dikenal baik dari wisatawan lokal maupun wisatawan mancanegara.Dalam rangka mengenalkan potensi alam di Kabupaten Bintan terutama disektor industri pariwisata kepada Pemerintah Pusat untuk memperlihatkan kawasan pariwisata misalnya Lagoi dan pariwisata di kawasan pantai Trikora dengan segala potensi alamnya. Pemkab Bintan yang begitu baik memanage perkembangan industri pariwisata di Bintan, sehingga dapat memberikan kontribusi besar pada kunjungan wisman ke Indonesia. Banyak yang mengagumi keindahan Bintan diharapkan kedepan Bintan dapat terus berkembang dan menarik wisatawan lebih banyak lagi.

Konsumen dalam hal ini adalah wisatawan dihadapkan banyak pilihan dan penawaran ketika mereka memilih destinasi wisata. Sehingga saat ini harapan yang diinginkan oleh konsumen mengalami perubahan, dimana tidak hanya sekedar memilih objek wisata yang bagus dan unik, namun juga memperhatikan pengalaman yang mereka rasakan, suasana, bahkan membandingkan dengan penawaran yang diberikan oleh destinasi wisata lainnya. Seiring dengan itu diharapkan dari pengalaman yang dirasakan perlu mendapat perhatian para pebisnis di bidang pariwisata dalam memuaskan konsumennya dan memenangkan persaingan.

Kabupaten Bintan yang memiliki banyak destinasi pariwisata yang pantai untuk 
dikunjungi. Beberapa destinasi pariwisata memiliki keunggulan masing-masing. Namun dari pengamatan awal meski objek wisata yang ada di Kabupaten Bintan yang dikelola oleh pihak swasta banyak memberikan kepuasan dan pengalaman yang berkesan bagi pariwisata lokal ataupun wisatawan mancanegara, tetapi berbeda dengan objek wisata yang dikelola oleh bukan swasta masih dirasakan kurang memberikan fasilitas dan pelayanan yang memadai, meski demikian bagi sebagian wisatawan lokal yang butuh hiburan mau tidak mau menerima keadaan tersebut.

\section{Perumusan Masalah}

Permasalahan dalam penelitian ini adalah; "Apakah customer experience berpengaruh signifikan baik secara simultan maupun secara partial terhadap customer satisfaction wisatawan di Kabupaten Bintan"

\section{Tujuan Penelitian}

Tujuan penelitian ini adalah untuk mengetahui pengaruh variabel customer experience terhadap customer satisfaction wisatawan di Kabupaten Bintan baik secara partial maupun secara simultan

\section{Tinjauan Teori}

\section{Customer Experience}

Customer experience berasal dari interaksi antara pelanggan dan produk, perusahaan atau bagian dari organisasi. Yang bisa mengakibatkan reaksi. Pengalaman ini benarbenar pribadi dan menyiratkan keterlibatan pelanggan (konsumen) pada tingkat yang berbeda (baik secara rasional, emosional, sensorik, fisik dan spritual). Hal ini yang dijelaskan oleh Gentile, and Noci (2007).

Menurut Colin Shaw and John Ivens (dalam Meyer and Schwager ,2007):

"The customer experinece is a blend of a company's physical performance and the emotions evoked, intuitively measured againts customernexpectation across all moment of contact".

Maksudnya adalah pengalaman adalah tanggapan pelanggan secara internal dan subjektif sebagai akibat dan interaksi secara langsung maupun tidak langsung dengan perubahan.

Dari definisi diatas dapat dijelaskan bahwa terdapat dua hal dalam customer experince yaitu fisik dan emosional. Dan dari kata blend dijelaskan bahwa customer experience tidak dipengaruhi satu unsur saja, tetapi gabungan dari banyak aspek antara lain product, service, brand,channel, promotion. Komponen tersebut dapat dikelompokkan menjadi lima dimensi customer experience yang dikemukakan oleh Schmitt (2004) sebagai bentuk aplikasi penedekatan yang dapat dilakukan perusahaan untuk memberikan pengalaman kepada konsumennya. Kelima dimensi itu yaitu Sense, Feel, Think, Act dan Relate.

\section{Customer Satisfaction}

Customer Satisfaction didefinisikan oleh Kotler dan Keller (2009) bahwa kepuasan konsumen merupakan fungsi dari seberapa sesuainya harapan pembeli produk dengan kinerja yang dipikirkan pembeli atas produk tersebut. Menurut Westbrook dan Reiley (dalam Tjiptono, 2008) bahwa pengertian kepuasan pelanggan sebagai respon emosional terhadap pengalaman-pengalaman berkaitan dengan produk atau jasa tertentu yang dibeli bahkan pola perilkau serta pasar secara keseluruhan.

Seiring dengan itu menurut Freddy Rangkuti, (2002:56) bahwa kepuasan atau ketidakpuasan pelanggan adalah respon konsumen terhadap evaluasi ketidakpuasan atau diskonfirmasi yang dirasakan anatar harapan sebelumnya dengan kinerja aktual dari produk/jasa yang dirasakan pemakai. Sejalan dengan itu Kotler (2012) juga mengatakan:

"Customer satisfactions is a person's feeling of pleasure or disappointment resulting from comparing a product's 
perceived performance (or outcome) in relation to his or her expectation"

Lupiyoadi (2011) menjelaskan bahwa menentukan tingkat kepuasan konsumen dipengaruhi oleh lima faktor yaitu kualitas produk, kualitas layanan, faktor emosional, harga serta biaya dan kemudahan mendapatkan produk/jasa. Selanjutnya Yamit (2003) mengungkapkan bahwa kepuasan pelanggan ditentukan oleh kualitas fenomena dalam pelayanan di lapangan. Apabila pelayanan (service) tidak sama atau tidak sesuai dengan harapan (expectation) pelanggan, maka dimata pelanggan, pelayanan yang diberikan dinilai jelek dan tidak memuaskan.

\section{Kerangka Konseptual}

Berdasarkan uraian teori di ats, dapat digambarkan bahwa dimensi pada customer experience merupakan faktor yang memberikan pengaruh terhadap kepuasan wisatawan (konsumen). Sehingga dalam penelitian ini hipotesa dianalisa untuk membuktikan kebenaran model penelitian ini.

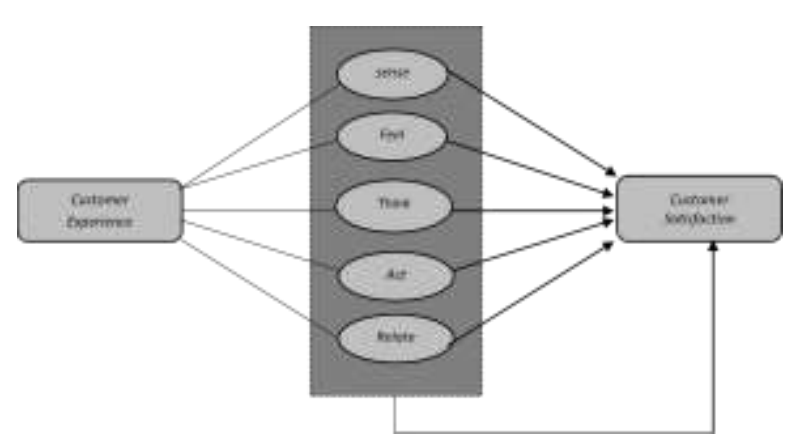

Gambar 1.2 Kerangka konseptual

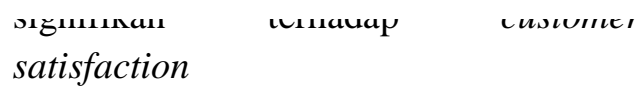

$\mathrm{H} 2$ : diduga dimensi pada variabel customer experience secara simultan berpengaruh signifikan terhadap customer satisfaction

\section{Metodologi Penelitian}

Sesuai dengan tujuan penelitian, maka penelitian inib bersifat deskriptif (Descriptive), maksudnya adalah memberikan gambaran dan mengungkapkan adanya Pengaruh Customer
Experience terhadap Customer Satisfaction. Untuk menguji hipotesistersebut dilakukan suatu jenis penelitian yang bersifat verifikatif (Verificative), yang gunanya untuk menguji kebenaran dari suatu hipotesis yang memakai perhitungan - perhitungan statistika (Sugiono:2000;63).

Mengingat penelitian ini bersifat deskriptif dan verifikatif, maka metode penelitian yang digunakan adalah metode descriptive survey dan explanatory survey. Explanatory survey adalah suatu metode penelitian yang berusaha untuk mencari kejelasan hubungan antara variabel dalam penelitian.Tipe ini adalah causal relationship, guna menjawab Pengaruh Customer Experience terhadap Customer Satisfaction wisatawan Di Kabupaten Bintan Provinsi Kepulauan Riau.

\section{Pengambilan Sampel}

Pengambilan sampel yang penulis lakukan adalah menggunakan Accidental Sampling yaitu teknik penentuan sampel berdasarkan kebetulan bertemu dengan responden dapat ligunakan sebagai sampel, bila dipandang rang yang kebetulan ditemuinya itu cocok :ebagai sumber data (Sugiono, 2009). Jigunakan teknik acidental sampling tersebut ıdalah dengan pengertian bahwa tidak nungkin semua populasi dapat diinterview, zarena keterbatasan tenaga, waktu dan biaya, ınggota populasi anggota populasi lainnya lianggap homogen. Homogen dalam sengertian sampel ini adalah responden yang memiliki kesamaan dalam kunjungan destinasi wisata di Kabupaten Bintan,

Teknik pengambilan sampel yang dipakai adalah sampling acak sederhana (simple random sampling) yang merupakan bagian dari probability sampling. Pada sampling acak sederhana, setiap elemen dari populasi mempunyai peluang yang sama dan diketahui untuk terpilih menjadi subjek. Cara pengambilan sampel ini mempunyai paling sedikit bias dan menawarkan generalizability yang baik (Umar, 2003). 
Jumlah responden dalam penelitian ini akan dicari berdasarkan rumus Slovin (Umar, 2003):

$$
n=\frac{N}{\left(1+N e^{2}\right)}
$$

Keterangan:

$\mathrm{n} \quad=$ ukuran sampel

$\mathrm{N} \quad=$ ukuran populasi

$\mathrm{e} \quad=$ persentase kelonggaran

ketidaktelitian karena kesalahan contoh yang masih dapat ditolerir (pada penelitian ini ditetapkan $7.5 \%$ )

Perhitungannya sebagai berikut:

$$
n=\frac{90}{\left(1+90 \times 0.075^{2}\right)}=59,75 \approx 60
$$

\section{Teknik Analisa Data}

Terdapat beberapa tahap analisa yang dilakukan hingga menjawab hipotesa penelitian, antara lain:

\section{Analisa regresi Linier Berganda}

Analisa ini digunkaan untuk melihat pengaruh sebab akibat dari masing-masing variabel independen maupun dpenden, dimana sesuai hipotesa penelitian yaitu dari hasil uji $\mathrm{F}$ (untuk melihat pengaruh secara simultan), Uji t (untuk elihat pengaruh secara koefisien determinasi (untuk melihat besarnya pengaruh perubahan model variabel dependen), serta koefisien beta standar (untuk melihat variabel/dimensi manakah yang memberikan penagruh paking signifikan dan dominan dalam model penelitian ini.

\section{Koefisien Korelasi}

Koefisien korelasi digunakan untuk mengetahui keeratan hubungan antar variabel pada penelitian ini. Nilai dari koefisien korelasi berkisar antara -1 sampai 1 dimana -1 berarti terdapat hubungan negatif (berkebalikan) yang sempurna 0 berarti tidak terdapat hubungan sama sekali, 1 berarti hubungan positif sempurna.

\section{Uji Asumsi Klasik}

Uji asumsi klasik melalui uji multikolonieritas, uji heteroskedastisitas, dan uji normalitas sebagai pembuktian untuk melihat ketepatan variabel yang digunakan dalam model regresi dari analisa yang telah dilakukan.

\section{Analisis dan Pembahasan}

\section{Profil Responden}

Dalam penelitian ini dari sampel sebanyak 60 orang,dimana $58 \%$ adalah perempuan dan $42 \%$ adalah laki-laki, dengan rata-rata usia 75\% di bawah 30 tahun. Pendapatan dan pengeluaran responden pun beragam dan menunjukkan bahwa tingkat ekonomi wisatawan masih rata-rata golongan ekonomi menengah, yaitu Rp.1.000.000,- sampai dengan Rp.3.500.000,-

Sedangkan dari behavior dari $72 \%$ responden, kebiasaan menghabiskan liburan dengan mengunjungi objek wisata yang ada di Kabupaten Bintan dan menyukai objek wisata yang ditawarkan oleh pihak pengelola, kebanyakkan wisatawan menikmati alam pantai yang ada di Kabupten Bintan. Namun demikian yang menjadi pertimbangan memilih wisata bahari, $54 \%$ dari responden lebih mempertimbangkan pengalaman yang mereka dapatkan.

Mengenai objek wisata yang ada di Kabupaten Bintan sebagian besar adalah wisata bahari, dan responden memanfaatkan sebagai tempat tujuan/destinasi wisata bersama keluarga dan saudara, karena mengetahui objek wisata dari informasi, dari mulut ke mulut. Mayoritas responden menyukai suasana yang ada disana, fasilitas yang baik, sarana dan prasarana yang memadai serta transportasi yang baik. Dan 92\% dari responden merasa puas dan ingin kembali mengunjungi objek wisata yang ada di Kabupaten Bintan sebagai pilihan melakukan rekreasi.

\section{Analisa Faktor}

Pada penelitian ini, analisa faktor digunakan sebagai alat analisa untuk 
mengkonfirmasi apakah seluruh indikator pertanyaan pada masing-masing dimensi mampu menjelaskan dimensi tersebut.

Dari kelima dimensi dalam variabel independen customer experience, masingmasing dimensi menunjukkan nilai KMOMSA dan faktor loading lebih besar dari 0.50, dengan nilai signifikan Barlet's test semuanya kurang dari 0.1. dengan demikian dapat dikatakan bahwa masing-masing item pertanyaan benar-benar menjawab dimensi penelitian, dan dimensi tersebut dapat dianalisa lebih lanjut. Seperti pada tabel 1 di bawah ini:

\begin{tabular}{|c|c|c|c|c|c|}
\hline $\begin{array}{c}\text { Dimens } \\
\text { i }\end{array}$ & $\begin{array}{c}\text { Indikato } \\
\mathbf{r}\end{array}$ & $\begin{array}{c}\text { KMO } \\
- \\
\text { MSA }\end{array}$ & $\begin{array}{c}\text { Sig. } \\
\text { Barlett' } \\
\text { s }\end{array}$ & $\begin{array}{c}\text { Faktor } \\
\text { Loadin } \\
\mathrm{g}\end{array}$ & $\begin{array}{c}\text { Keterang } \\
\text { an }\end{array}$ \\
\hline $\begin{array}{c}\text { Sense } \\
\text { (X1) }\end{array}$ & $\begin{array}{c}\text { X.1.1 } \\
\text { X.1.2 } \\
\text { X.1.3 } \\
\text { X.1.4 } \\
\text { X.1.5 } \\
\text { X.1.6 } \\
\text { X.1.7 } \\
\text { X.1.8 } \\
\text { X.1.9 } \\
\text { X.1.10 }\end{array}$ & 0.751 & 0,000 & $\begin{array}{l}0.670 \\
0.708 \\
0.797 \\
0.682 \\
0.643 \\
0.741 \\
0.723 \\
0.939 \\
0.914 \\
0.714\end{array}$ & $\begin{array}{c}\text { Dapat } \\
\text { diteruskan }\end{array}$ \\
\hline $\begin{array}{l}\text { Feel } \\
\text { (X2) }\end{array}$ & $\begin{array}{l}\text { X.2.1 } \\
\text { X.2.2 } \\
\text { X.2.3 } \\
\text { X.2.4 } \\
\text { X.2.5 } \\
\text { X.2.6 }\end{array}$ & 0.718 & 0.000 & $\begin{array}{l}0.750 \\
0.619 \\
0.683 \\
0.695 \\
0.730 \\
0.764\end{array}$ & $\begin{array}{c}\text { Dapat } \\
\text { diteruskan }\end{array}$ \\
\hline $\begin{array}{c}\text { Think } \\
\text { (X3) }\end{array}$ & $\begin{array}{l}\text { X.3.1 } \\
\text { X.3.2 } \\
\text { X.3.3 } \\
\text { X.3.4 }\end{array}$ & 0.713 & 0.000 & $\begin{array}{l}0.845 \\
0.776 \\
0.711 \\
0.702\end{array}$ & $\begin{array}{c}\text { Dapat } \\
\text { diteruskan }\end{array}$ \\
\hline $\begin{array}{l}A c t \\
\text { (X4) }\end{array}$ & $\begin{array}{l}\text { X.4.1 } \\
\text { X.4.2 }\end{array}$ & 0.500 & 0.000 & $\begin{array}{l}0.789 \\
0.784\end{array}$ & $\begin{array}{c}\text { Dapat } \\
\text { diteruskan }\end{array}$ \\
\hline $\begin{array}{c}\text { Relate } \\
\text { (X5) }\end{array}$ & $\begin{array}{l}X .5 .1 \\
X .5 .2 \\
X .5 .3\end{array}$ & 0.724 & 0.000 & $\begin{array}{l}0.670 \\
0.677 \\
0.879\end{array}$ & $\begin{array}{c}\text { Dapat } \\
\text { diteruskan }\end{array}$ \\
\hline
\end{tabular}

Tabel 2

Analisa Faktor Variabel Customer Satisfaction

Sumber: data diolah, 2017

\begin{tabular}{cccccc}
\hline Dimensi & Indikator & $\begin{array}{c}\text { KMO } \\
- \\
\text { MSA }\end{array}$ & $\begin{array}{c}\text { Sig. } \\
\text { Barlett's }\end{array}$ & $\begin{array}{c}\text { Faktor } \\
\text { Loading }\end{array}$ & Keterangan \\
\hline $\begin{array}{c}\text { Customer } \\
\begin{array}{c}\text { Satisfaction } \\
\text { (Y) }\end{array}\end{array}$ & Y.1 & & & 0.856 & $\begin{array}{c}\text { Dapat } \\
\text { diteruskan }\end{array}$ \\
\hline
\end{tabular}

Dari variabel dependen Customer experience, masing-masing indikator pertanyaan nilai KMO-MSA dan faktor loading lebih besar dari
0,50, dengan nilai signifikan Barlett's Test kurang dari 0,1. Dengan demikian dapat dijelaskan bahwa item pertanyaan benar-benar menjawab variabel penelitian dapat di analisa lebih lanjut.

\section{Regresi Linear Berganda}

Regresi antara sense, feel, think, act dan relate di destinasi wisata di Kabupaten Bintan terhadap customer satisfactionwisatawan menghasilkan nilai korelasi sebesar0,866 menunjukkan adanya hubungan kuat antara sense, feel, think, act dan relate dengan customer satisfaction wisatawan. Sedangkan nilai koefien determinasi atau $\mathbf{R}$ Square yang dihasilkan sebesar 0,786 menunjukkan variasi perubahan customer satisfaction wisatawan pada destinasi wisata di kabupaten Bintan dapat dijelaskan oleh variasi sense, feel, think, act dan relate sebesar $86,6 \%$ sedangkan sisanya $13,4 \%$ dijelaskan oleh faktor lain diluar analisa peneliti.

Tabel.3

Model Summary

\begin{tabular}{|l|r|r|r|r|}
\hline Model & R & R Square & \multicolumn{1}{|c|}{$\begin{array}{c}\text { Adjusted R } \\
\text { Square }\end{array}$} & $\begin{array}{c}\text { Std. Error of } \\
\text { the } \\
\text { Estimate }\end{array}$ \\
\hline 1 & .866 & .786 & .260 & .62075 \\
\hline
\end{tabular}

Sumber: data diolah, 2017

Uji F

Berdasarkan analisa yang dilakukan, hasil dari uji $\mathrm{F}$ menunjukkan nilai Fhitung sebesar 12,926 dimana lebih besar dari Ftabel 2,4 (df1 $=4, \mathrm{df2}=55, \alpha=0,05)$ dengan nilai signifikansi sebesar 0,000 kurang dari 0,05 , maka dapat disimpulkan bahwa kelima variabel independen,(sense, feel, think, act dan relate) secara simultan berpengaruh signifikan terhadap customer satisfaction wisatawan pada destinasi wisata di Kabupaten Bintan (H0 ditolak dan Ha diterima)

Tabel.4

Hasil Uji F 
$\operatorname{ANOVA(b)}$

\begin{tabular}{|rl|r|r|r|r|r|}
\hline \multicolumn{1}{|c|}{ Model } & \multicolumn{1}{c|}{$\begin{array}{c}\text { Sum of } \\
\text { Squares }\end{array}$} & \multicolumn{1}{c|}{ df } & $\begin{array}{c}\text { Mean } \\
\text { Square }\end{array}$ & \multicolumn{1}{c|}{ F } & Sig. \\
\hline 1 & Regression & 18.012 & 25 & 3.720 & 12.926 & $.000(\mathrm{a})$ \\
. & Residual & 12.722 & 34 & .374 & & \\
& Total & 30.733 & 59 & & & \\
\hline
\end{tabular}

Sumber: data diolah, 2017

Uji t

Tabel.5

Hasil Uji t

\begin{tabular}{|ll|r|r|r|c|}
\hline & Model & \multicolumn{1}{c|}{ B } & \multicolumn{1}{c|}{$\mathrm{T}_{\text {hitung }}$} & \multicolumn{1}{c|}{ Sig } & status \\
\hline 1. & Sense (X1) & .302 & 2.512 & .054 & sig \\
& Feel (X2) & .023 & 2.189 & .058 & sig \\
Think & .261 & 2.297 & .015 & sig \\
(X3) & .203 & 2.105 & .021 & sig \\
Act (X4) & .073 & 2.363 & .039 & sig \\
Relate & .073 \\
(X5) & &
\end{tabular}

Sumber: data diolah, 2017

Dari hasil Uji $\mathrm{t}$ pada tabel 5 diatas menunjukkan $\mathrm{t}$ hitung $>\mathrm{t}$ tabel $(\mathrm{df}=$ residual, $\alpha / 2-0,025)$ atau nilai signifikan < $0,05 \quad(\alpha=5 \%)$, maka $\mathrm{H}_{0}$ di tolak dan $\mathrm{H}_{\mathrm{a}}$ diterima, sehingga dapat disimpulkan bahwa variabel bebas secara parsial berpengaruh signifikan terhadap variabel terikat. Pada penelitian ini $\mathrm{t}$ hitung $>\mathrm{t}$ tabel $(0,00404)$. Sehingga dapat dikatakan bahwa kelima dimensi tersebut berpengaruh signifikan terhadap customer satisfaction. Maka dapat disimpulkan bahwa secara partial, semua dimensi dari variabel customer experience berpengaruh signifikan terhadap customer satisfaction wisatawan pada destinasi Pariwisata Kabupaten Bintan. $\left(\mathrm{H}_{0}\right.$ ditolak dan $\mathrm{H}_{\mathrm{a}}$ diterima)

\section{Uji Asumsi Klasik}

Hasil uji asumsi klasik menunjukkan nilai tolerance kelima variabel bebas di atas angka 0,10 dengan nilai VIF semuanya di bawah angka 10, sehingga dapat disimpulkan model regresi bebas dari multikolinieritas. Begitu pula dengan scatter poly yang menunjukkan bahwa titik-titik tidak membentuk pola tertentu dan titik-titik menyebar di atas dan di bawah angka nol sumbu $\mathrm{Y}$, sehingga dapat disimpulkan tidak terjadi heteroskedastisitas dalam model regresi. Dan titik-titik terkumpul di sekitas garis lurus pada uji normalitas menujukkan bahwa residual model regresi mengikuti distribusi normal.

\section{Analisa Pengaruh Dimensi Customer Experience Terhadap Customer Satisfaction \\ Pada variabel ini dimensi Sense} berpengaruh paling besar terhadap customer satisfaction wisatawan pada destinasi pariwisata kabupaten Bintan. Dimensi sense sendiri berhubungan dengan segala pengalaman yang diterima oleh konsumen dan dapat dirasakan langsung oleh panca indra mereka, terutama dari konsep interior maupun eksterior lokasi, maupun produk wisata serta sarana prasarana yang mencukupi. Seperti hasil pengolahan data yang telah dilakukan, pengalaman yang benar-benar langsung dirasakan oleh wisatawan baik lokal maupun mancanegara adalah suasana alam, dan inilah yang disukai olek wisatawan. Sehingga hanya dengan merasakan keunikan alam akan membuat wisatawan puas terhadap destinasi wisatanya.

Berikutnya adalah relate, dimana relate ini berhubungan dengan keinginan konsumen untuk mendapatkan rekomendasi pengalaman orang lain tentang Objek wisata di kabupaten Bintan, maupun keinginan wisatawan untuk merekomendasikan keindahan yang ada pada objek wisata Kabupaten Bintan kepada orang lain. Ketika banyak orang merekomendasikan lokasi wisata tersebut kepada yang lain dan pengalaman yang diterima sesuai dengan yang direkomendasikan, maka wisatawan, makakonsumen akan merasa puas. Dengan demikian semakin banyak orang yang memberikan rekomendasi akan membuat wisatawan yakin bahwa objek wisata di Kabupaten Bintan memang memiliki sesuatu yang akan memberikan pengalaman berbeda bagi mereka.

Dimensi think yang berhubungan dengan keunikan yang ada pada setiap objek wisata yang ditawarkan juga memberikan 
pengalaman cukup besar terhadap kepuasan wisatawan. Hal ini karena bagi wisatawan, tujuan destinasi wisata tentu melihat produk wisata yang ditawarkan memiliki keunikan, terutama suasana dan keindahan alam Kabupaten Bintan, sehingga memberikan pengalaman khusus yang diterima wisatawan untuk membuat mereka berfikir akan keunikan Kabupaten Bintan

Dimensi pengaruhnya tidak terlalu besar terhadap kepuasan wisatawan adalah feel, dimana diemnsi feel berhubungan dengan pengalaman yang dirasakan oleh wisatawan dari interaksinya dengan pengelola melalui pelayanan yang diberikan. Seperti yang dijelaskan sebelumnya wisatawan banyak menghabiskan waktu mereka untuk berbincang-bincang, bermain karena kenyamanan yang mereka dapatkan. Dari hal ini, konsumen tidak banyak berinteraksi dengan karyawan selain ketika menyewa alatalat, memesan makanan dan minuman, pembayaran. Jadi tidak banyak pengalaman yang didapatkan oleh wisatawan dari diemnsi ini. Selama objek wisata memberikan pelayanan yang baik, dan tidak ada pengalaman buruk yang dirasakan oleh wisatawan, maka wisatawan akan tetap puas terhadap destinasi pariwisata di Kabupaten Bintan.

Pengaruhnya paling kecil adalah kepuasan wisatawan terhadap dimensi act yang berhubungan dengan keterlibatan wisatawan terhadap aktivitas atau event yang dilaksanakan di lokasi wisatawan tersebut. Dimensi ini memberikan pengaruh paling kecil karena objek wisata di Kabupaten Bintan tidak banyak melaksanakan event besar, sedikitnya hanya 1 kali dalam setahun. Tapi jika lokasinya bisa dijangkau dengan mudah oleh wisatawan dan murah tapi denga fasilitas memadai tetap memberikan kepuasan kepada wisatawan.

\section{Kesimpulan dan Saran Daftar Pustaka}

\section{Kesimpulan}

Berdasarkan hasil yang didapat melalui analisa data dalam penelitian mengenai pengaruh customer experience terhadap customer satisfaction wisatawan pada destinasi wisata Kabupaten Bintan, terdapat beberapa kesimpulan yang dapat di ambil yaitu:

1. Secara simultan dimensi sense, feel, think, act dan relate berpegaruh signifikan pada customer satisfaction.

2. Secara partial dimensi sense, feel, think, act dan relate seluruhnya berpengaruh secara signifikan terhadap customer satisfaction

\section{Saran}

1. Seluruh variabel bebas dalam penelitian yakni sense, feel, think, act dan relate memberikan pengaruh terhadap satisfaction customer. Oleh karena itu, perlu dipertahankan dan ditingkatkan oleh pihak pengelola terutama pemerintah Kabupaten Bintan agar wisatawan baik mancanegara maupun domestik semakin meningkatkan kunjungannya di Kabupaten Bintan.

2. Sense berpengaruh paling besar terhadap customer satisfaction wisatawan pada destinasi pariwisata Pemerintah Kabuptaen Bintan karena pengalaman akan mempengaruhi niat wisatawan dalam mengunjungi objek wisata yang ada di Kabupaten Bintan.

3. Mengingat variabel bebas dalam penelitian in merupakan hal yang sangat penting dalam mempengaruhi satisfaction customer diharapkan hasil penelitian ini dapat dipakai sebagai acuan bagi peneliti selanjutnya untuk mengembangkan penelitian ini dengan mempertimbangkan variabelvariabel lain yang merupakan variabel di luar variabel yang sudah masuk dalam penelitian ini 
Badan Pusat Statistik Provinsi Kepulauan Riau hasil Susenas 2008-2012, No. 43/07/Th.XVI,1 Juli 2016

Fredy Rangkuti, 2003, Measuring Customer Satisfaction:Gaining Customer relationship Strategy, cetakan kedua, Gramedia Pustaka Utama, Jakarta

Gentile, C., Nicola Spiller \& Giuliano Noci, 2007, How to Sustain the Customer Experience: An Overview of Experience Components thet Co-create Value Will the Customer. European Management Journal Vol 25. No.5

Husein Umar, 2005, Manajemen Riset dan Perilaku Konsumen, PT. Gramedia Pusat, Jakarta.

Kotler Philip dan Kevin Lane Keller, 2009, Manajemen Pemasaran, edisi ketigabelas Jilid 1, alih bahasa oleh Bob Sabran, Penerbit Erlangga, Jakarta

Kotler, Philip and Gary M. Amstrong, 2012, Principles of Marketing, Pearson, New Jersey USA
Lupiyoadi Rambat dan Hamdani, 2011, Manajemen Pemasaran Jasa, edisi 2, Jakarta:Salemba Empat

Meyer, C., \& Schwager, A. (2007). Understanding customer experience. Harvard Business Review, 2, 117-126.

Schmitt, Bernd H. 2004. Experiential Marketing : How To Get Customers To Sense, Feel, Think, Act And Relate To Your Company And Brand. New York: Free Press

Sugiyono. 2009. Metode Penelitian Bisnis. Cetakan Keempat belas. Bandung: CV. Alfabeta.Suhartini Karim.(2007)

Tjiptono, Fandy, 2008. Strategi Pemasaran. Edisi kedua. Yogyakarta: Andi.

Yamit, Zulian, 2010, Manajemen Kualitas Produk Dan Jasa, Yokyakarta, Ekonesia

http://id.wikipedia.org/w/index.php?title= Kabupaten_Bintan 